\title{
Aloe-Gel Coating for Delaying Physicochemical Change of Fresh-Cut Mango
}

\author{
Luh Suriati *, I Putu Candra, I Komang Supardika, \\ Department of Food Science and Technology Faculty of Agriculture, Warmadewa University, Indonesia \\ *suryati_luh@yahoo.com \\ *** komangsupardika91@gmail.com
}

\begin{abstract}
Fresh-cut arumanis mango is a current popular product, stimulated by lifestyle and community needs for quality fruit with little preparation. Stripping and cutting spur the damage of fresh-cut mangoes faster than whole mangoes. Aloe vera gel coating is an alternative to maintain the characteristics of fresh-cut mangoes and extend shelf life. This study aims to delay the physicochemical change of fresh-cut mango with aloe vera edible coating. The design used is a completely randomized design (CDR) of two factors, namely the ratio of dilution of aloe vera gel with aqua dest 1:0, 1:1, and 1:2. Factor II, duration of immersion 1, 2, and 3 minutes with observations on the $5^{\text {th }}$ and $10^{\text {th }}$ days stored at cold temperatures $(7 \pm 1){ }^{\circ} \mathrm{C}$. Observation variables include physical properties, namely weight loss, color, and texture. Whereas observations of chemical properties, namely $\mathrm{pH}$, total soluble solids, water content, and vitamin $C$. The best results were obtained in a combination of 1:1 aloe vera gel with 3 minutes immersion with a weight loss value of $1.40 \%$, color $b(\Delta E) 63.12$, texture $6.82 \mathrm{~N}, \mathrm{pH} 4.65$, TSS $24.60^{\circ}$ Brix, moisture content $83.51 \%$ and vitamin C $35.60 \mathrm{mg} / 100 \mathrm{~g}$ ).
\end{abstract}

Keyword: Fresh-cut, Edible Coating, Aloe Vera Gel

\section{Introduction}

Mango (Mangifera indica L.) is a fruit that is famous throughout the world for its delicious and fresh taste. Mangoes contain vitamins C, A, D, E, K, B1, B2, B3, B5, B6, and B9. And it contains sugar, fiber, carbohydrates, iron, phosphorus, magnesium, and calories. Apart from being beneficial for health, mangoes can also prevent cancer, boost the immune system, maintain healthy bones and eyes, control blood pressure, avoid asthma, maintain heart health, overcome constipation, and improve brain health [1] [2]. Lifestyle changes are completely practical and people are busy wanting food that is ready for consumption without requiring preparation time. The minimal process product is one product that can overcome this which is currently very popular. Minimal process products are products made by cutting, slicing, peeling with minimal or no heating and can maintain the freshness of the fruit [3] [4]. The peeled fruit will quickly experience damage, therefore it needs to be treated such as storage at low temperatures, decreased moisture content, modified atmosphere packaging, use of preservatives, and edible coating treatment with aloe vera gel [5].

The abundance of dangerous preservatives causes concern in the community. Several natural ingredients can be used as preservatives as well as edible coatings, including polysaccharides (carbohydrates), proteins, and lipids. The edible coating has many advantages such as being biodegradable, biocompatible, aesthetically pleasing, and its ability to act as a barrier to oxygen and physical stress during transportation. The polysaccharide-based edible coating acts as a permeable membrane that is selective against the exchange of $\mathrm{O}_{2}$ and $\mathrm{CO}_{2}$ gases so that it can reduce the respiration rate in fruits [6].

Aloe vera gel consists of polysaccharides that contain many functional components such as Acemannan which can inhibit post-harvest damage to fresh food products, has antidiabetic, anticancer, and antimicrobial activity, and increases the proliferation of injured cells. In addition, 
aloe vera gel is also able to maintain moisture by controlling water loss and the exchange of watersoluble components [7]. The edible coating is a thin layer made of edible material, formed on top of food components which functions as an inhibitor for mass transfer (e.g., moisture, oxygen, fat, and solutes) and as a carrier of food ingredients or additives and to improve food handling [8]. The application of aloe vera gel edible coating on mangoes by coating it at a certain concentration and immersion time is one step to maintain the shelf life of fresh-cut mangoes. Therefore, it is necessary to research the application of edible coating from aloe vera gel on fresh-cut mangoes.

\section{Material and Methods}

This research was conducted from February-April 2020 at the Processing Laboratory of the Faculty of Agriculture, Warmadewa University, while the analysis was carried out at the Food Analysis Laboratory, Faculty of Agriculture, Warmadewa University. The materials used in the process of applying an edible coating from aloe vera gel on mangoes are fresh arumanis mangoes fruit obtained from mangoes farmers in Patas Village, Buleleng Regency, aloe vera leaves, ascorbic acid, sorbic acid, citric acid, chlorine solution, boiled water, alcohol 70\%, distilled water, and diluents. The tools used are wearing bled, fine digital scales, basins, refrigerators with the RSA brand, stirring spoons, tablespoons, chopsticks, knives, plastic gloves, masks, bunsen, plastic cups, Styrofoam containers, plastic wrapping, plastic cutting boards, containers large size, as well as a colander. For analysis, the tools used are dropper pipettes, volumetric pipettes, aluminum plates, porcelain dishes, Petri dishes, measuring cups, Erlenmeyer, analytical balance, $30^{\circ} \mathrm{C}$ incubator, Minolta CR-300 chromameter, $\mathrm{pH}$ meter with Hanna brand, refractometer with Atago brand, stirring rod, and test tube.

This research is a factorial experiment with a completely randomized design (CRD) consisting of 2 (two) factors, namely: The first factor is the ratio of aloe vera gel dilution to distilled water consisting of 1:0,1:1, and 1:2. The second factor is the immersion time which consists of 1 minute, 2 minutes, and 3 minutes. Each treatment was repeated 3 times to obtain 27 experimental units. The data obtained were then analyzed for variance and if there was a real or very real influence between the treatments then it was continued with the LSD 5\% and 1\% test. The research stages consisted of making aloe vera gel, preparing fresh-cut mangoes, and the edible coating process. Aloe vera leaves are sorted and washed under running water, then soaked in $200 \mathrm{ppm}$ chlorine solution for 30 minutes. Then rinsed with boiled water at a temperature of $60^{\circ} \mathrm{C}$, then trimming and filleting. Furthermore, rinsed with boiled water, then in a blender for 5 minutes. After becoming a gel, the additives of $0.05 \%$ ascorbic acid, $0.05 \%$ citric acid, and $0.05 \%$ sorbic acid were added. Preparation of fresh-cut mangoes begins with pre-cooling and sorting the mangoes, then peeling them. After that, the pulp is cut to the size of $4 \times 4 \times 1.5$. The edible coating process is carried out by immersion technique according to treatment, then drained and dried with the help of a blower ( \pm 1 hour). After that, it was packed and stored at cold temperatures $(7 \pm 1){ }^{\circ} \mathrm{C}$ and observed on the 5 th and 10th days. The variables analyzed in this study include analysis of physical properties, namely weight loss, color, and texture. While the analysis of chemical properties is $\mathrm{pH}$, TSS, water content, and vitamin C. The data obtained from the results of the study were statistically analyzed using fingerprint analysis with a confidence level of $1 \%$ and $5 \%$ according to the design used. If there are differences between the treatments in the variance, then proceed with the Duncan's Multiple Range Test (DMRT).

\section{Results and Discussion}

The combination of aloe vera gel dilution ratio and immersion time had a significant effect $(\mathrm{p}$ $<0.05$ ) on the color of the 5th day, 10th day of TSS, and 10th day of vitamin C, and had a very significant effect $(\mathrm{p}<0.01)$ on the weight loss of the 5th day, the texture of the 5 th day, the $\mathrm{pH}$ of the 
5th day, the TSS of the 5th day, and the water content. However, there was no significant effect on weight loss on day 10 , day 10 color, texture on day $10, \mathrm{pH}$ on day 10 , and vitamin $\mathrm{C}$ on day 5 .

\subsection{Weight Loss}

Based on the observation shows that the combined ratio of dilution of aloe vera gel 1: 1 with immersion time of 3 minutes is the most effective treatment to maintain the weight loss of fresh-cut mangoes fruit. This is because the aloe vera gel which is applied in a 1: 1 ratio treatment with an immersion time of 3 minutes can suppress the respiration rate of the fruit so that weight loss can be suppressed. This opinion is in line with [9] and [10], where edible coatings made from polysaccharides applied to fruit can make weight loss relatively low. The edible coating has the ability as a good barrier to water and oxygen and can control the rate of respiration [8]. The average value of fresh-cut mangoes weight loss on day 5 and day 10 ranged from (1.40-7.95\%). The highest weight loss value was obtained in the combination of 1: 1 aloe vera gel dilution ratio with 2 minutes of immersion time and the lowest was the combination of 1: 1 aloe vera gel dilution ratio with 3 minutes immersion time. Weight loss is a process of reducing fruit weight due to the process of respiration, transpiration, and bacterial activity. Whereat the time of the respiration process oxygen is absorbed to burn relative materials to produce energy followed by the expenditure of combustion residues in the form of carbon dioxide and water. The water and gas produced, as well as the energy in the form of heat, will experience evaporation so that the fruit will shrink in weight [11].

Table 1

Weight Loss (\%) Fresh-cut on Day 5 and 10

\begin{tabular}{cccc}
\hline \multirow{2}{*}{ Treatment } & \multicolumn{3}{c}{ Mangoes (day) } \\
\cline { 2 - 4 } & 0 & 5 & 10 \\
\hline 1. & $0.00 \mathrm{a}$ & $2.44 \mathrm{a}$ & $5.48 \mathrm{a}$ \\
2. & $0.00 \mathrm{a}$ & $1.83 \mathrm{ab}$ & $4.36 \mathrm{a}$ \\
3. & $0.00 \mathrm{a}$ & $2.43 \mathrm{a}$ & $6.31 \mathrm{a}$ \\
4. & $0.00 \mathrm{a}$ & $2.02 \mathrm{ab}$ & $4.59 \mathrm{a}$ \\
5. & $0.00 \mathrm{a}$ & $2.28 \mathrm{a}$ & $7.95 \mathrm{a}$ \\
6. & $0.00 \mathrm{a}$ & $1.40 \mathrm{~b}$ & $2.93 \mathrm{a}$ \\
7. & $0.00 \mathrm{a}$ & $1.94 \mathrm{ab}$ & $3.93 \mathrm{a}$ \\
8. & $0.00 \mathrm{a}$ & $2.20 \mathrm{a}$ & $5.27 \mathrm{a}$ \\
9. & $0.00 \mathrm{a}$ & $2.41 \mathrm{a}$ & $5.61 \mathrm{a}$ \\
\hline
\end{tabular}

Note:

1. The ratio of aloe vera gel is 1: 0 for 1 minute.

2. Aloe vera gel ratio 1: 0 for 2 minutes

3. The ratio of aloe vera gel is $1: 0$ for 3 minutes.

4. The ratio of aloe vera gel is $1: 1$ for 1 minute.

5. Aloe vera gel ratio 1: 1 for 2 minutes
6. The ratio of aloe vera gel is $1: 1$ for 3 minutes

7. Aloe vera gel ratio 1: 2 for 1 minute

8 . The ratio of aloe vera gel is $1: 2$ for 2 minutes

9. The ratio of aloe vera gel is $1: 2$ for 3 minutes

\subsection{Color}

The combination of a 1:2 dilution ratio of aloe vera gel with an immersion time of 3 minutes can maintain the color of fresh-cut mangoes. The level of viscosity and the length of time of immersion affect the decrease in the color value of fresh-cut mangoes, where the higher the combination of aloe vera gel dilution ratio and the longer the immersion time, the lower the mango fresh-cut color value. This shows that the aloe vera gel can evenly coat the fresh-cut mangoes. This opinion is in line with [12], which states that the thickness and evenness of the edible coating on the fruit can inhibit the respiration rate and the fruit ripening process. The average value of fresh-cut mangoes color on the 5th and 10th days ranged from (50.49-103.36 $\Delta \mathrm{E})$. The highest color reduction value was obtained in the combination of aloe vera gel dilution ratio of 1: 0 with immersion time of 1 minute and the lowest was the combination of aloe vera gel dilution ratio of 1:2 with immersion time of 3 minutes. According to [13], the decrease in the color value of the fruit is the impact of chlorophyll degradation, 
pigment synthesis, and carotenoid synthesis along with fruit ripening due to chemical and physiological changes. This decrease in color value can be controlled by the presence of an aloe vera gel coating combined with the long immersion and storage time at low temperatures [14].

Table 2

Color b $(\Delta \mathrm{E})$ Fresh-Cut Mangoes During Storage Day 5 and 10

\begin{tabular}{cccc}
\hline Treatment & \multicolumn{3}{c}{ Mangoes (day) } \\
\cline { 2 - 4 } & 0 & 5 & 10 \\
\hline 1. & $91.75 \mathrm{a}$ & $100.36 \mathrm{a}$ & $50.49 \mathrm{a}$ \\
2. & $92.31 \mathrm{a}$ & $60.40 \mathrm{~b}$ & $59.07 \mathrm{a}$ \\
3. & $76.42 \mathrm{a}$ & $72.11 \mathrm{a}$ & $54.20 \mathrm{a}$ \\
4. & $77.32 \mathrm{a}$ & $71.79 \mathrm{a}$ & $62.83 \mathrm{a}$ \\
5. & $70.95 \mathrm{a}$ & $61.86 \mathrm{~b}$ & $61.55 \mathrm{a}$ \\
6. & $90.83 \mathrm{a}$ & $63.12 \mathrm{~b}$ & $55.82 \mathrm{a}$ \\
7. & $93.05 \mathrm{a}$ & $103.04 \mathrm{a}$ & $83.98 \mathrm{a}$ \\
8. & $62.11 \mathrm{a}$ & $53.16 \mathrm{~b}$ & $54.27 \mathrm{a}$ \\
9. & $52.54 \mathrm{a}$ & $54.21 \mathrm{~b}$ & $51.05 \mathrm{a}$ \\
\hline
\end{tabular}

\subsection{Texture}

The combination ratio of dilution of aloe vera gel 1: 0 with immersion time of 3 minutes can maintain the stability of the fresh-cut texture of the mangoes fruit during storage, where the higher the dilution ratio of aloe vera gel, the lower the value. the texture. This is due to the large number of water components trapped in the fruit cells, causing decay caused by anaerobic fermentation and the softening of the fruit texture [15]. In addition, the decrease in the texture value of fresh-cut mangoes is also caused by the ripening process of the mangoes which is marked by the change in insoluble pectin to water-soluble pectin, by more than $40 \%$. So that there is a decrease in cell turgor pressure. This is in line with the opinion (Hartanto and Sianturi, 2008) that insoluble pectinase enzymes become soluble pectin substances so that changes in the composition of this pectin substance will affect the hardness of fruits. The mean value of fresh-cut mangoes texture on day 5 and day 10 ranged from $(0.55-6.82 \mathrm{~N})$. The highest texture reduction value was obtained in the combination of aloe vera gel dilution ratio of 1: 0 with immersion time of 1 minute and the lowest was in the combination of aloe vera gel dilution ratio of 1: 0 with immersion time of 3 minutes. This shows that the aloe vera gel can maintain the fresh-cut texture of the manggoes fruit because it can coat it well and suppress the rate of respiration and transpiration to a minimum. This opinion is in line with [16], which states that mangoes are one of the climatic fruits that are still ripening after being harvested and edible coating can inhibit the rate of respiration and suppress the occurrence of softening of the fruit.

\section{Table 3}

Texture (N) Fresh-Cut Mangoes Day 5 and 10 (Newton)

\begin{tabular}{cccc}
\hline \multirow{2}{*}{ Treatment } & \multicolumn{3}{c}{ Mangoes (day) } \\
\cline { 2 - 4 } 1. & 0 & 5 & 10 \\
\hline 2. & $3.39 \mathrm{a}$ & $4.92 \mathrm{~b}$ & $0.55 \mathrm{~b}$ \\
3. & $3.39 \mathrm{a}$ & $2.31 \mathrm{~d}$ & $0.90 \mathrm{~b}$ \\
4. & $3.39 \mathrm{a}$ & $3.85 \mathrm{c}$ & $3.73 \mathrm{a}$ \\
5. & $3.39 \mathrm{a}$ & $6.65 \mathrm{a}$ & $5.44 \mathrm{a}$ \\
6. & $3.39 \mathrm{a}$ & $6.74 \mathrm{a}$ & $5.97 \mathrm{a}$ \\
7. & $3.39 \mathrm{a}$ & $6.82 \mathrm{a}$ & $5.63 \mathrm{a}$ \\
8. & $3.39 \mathrm{a}$ & $5.51 \mathrm{~b}$ & $4.19 \mathrm{a}$ \\
9. & $3.39 \mathrm{a}$ & $3.85 \mathrm{c}$ & $2.68 \mathrm{~b}$ \\
\hline
\end{tabular}

\section{$3.4 \mathrm{pH}$}


The combination of a 1: 0 dilution ratio of aloe vera gel with 1 minute immersion time can effectively maintain the $\mathrm{pH}$ stability of the fresh-cut mangoes fruit during storage. The thin edible coating is not able to slow down the respiration rate, thus accelerating the ripening of fresh-cut mangoes. This opinion is in line with [17] that during mangoes ripening there are biochemical and characteristic changes that can cause a decrease in $\mathrm{pH}$. In addition, the decrease in $\mathrm{pH}$ is also due to an increase in total acid during storage, apart from the physiological process of the fruit itself, acid can also be produced due to the fermentation process. This process produces organic acids such as lactic acid, butyric acid, and others. This increase in total acid lowers $\mathrm{pH}$ [18]. The average $\mathrm{pH}$ value of fresh-cut mangoes on the 5th and 10th days ranged from (3.48-4.66). The highest $\mathrm{pH}$ value was obtained in the combination of dilution ratio of aloe vera gel 1: 1 with immersion time of 2 minutes and the lowest was in the combination of dilution ratio of aloe vera gel 1: 1 with immersion time of 3 minutes. We can be sure that the edible coating can control the accelerated ripening process of fresh-cut mangoes. This opinion is also in line with [19], which states that the thickness of the edible coating can determine the fast and slow rate of respiration and transpirations, and to anticipate the occurrence of decay in cut fruit.

Table 4

The $\mathrm{pH}$ of the 5th and 10th Day of Fresh-Cut Mangoes

\begin{tabular}{cccc}
\hline Treatment & \multicolumn{3}{c}{ Mangoes (day) } \\
\cline { 2 - 4 } & 0 & 5 & 10 \\
\hline 1. & $4.58 \mathrm{a}$ & $4.29 \mathrm{~b}$ & $4.17 \mathrm{a}$ \\
2. & $4.58 \mathrm{a}$ & $3.82 \mathrm{c}$ & $3.99 \mathrm{a}$ \\
3. & $4.58 \mathrm{a}$ & $3.91 \mathrm{c}$ & $4.11 \mathrm{a}$ \\
4. & $4.58 \mathrm{a}$ & $4.20 \mathrm{~b}$ & $3.72 \mathrm{~b}$ \\
5. & $4.58 \mathrm{a}$ & $4.66 \mathrm{a}$ & $3.91 \mathrm{a}$ \\
6. & $4.58 \mathrm{a}$ & $4.65 \mathrm{a}$ & $3.48 \mathrm{~b}$ \\
7. & $4.58 \mathrm{a}$ & $3.91 \mathrm{c}$ & $3.86 \mathrm{ab}$ \\
8. & $4.58 \mathrm{a}$ & $3.94 \mathrm{c}$ & $3.87 \mathrm{ab}$ \\
9. & $4.58 \mathrm{a}$ & $3.63 \mathrm{~d}$ & $4.15 \mathrm{a}$ \\
\hline
\end{tabular}

\subsection{Total Soluble Solid}

Based on graphical observations, it shows that the combination of a 1: 2 dilution ratio of aloe vera gel with 1 minute immersion time can maintain the stability of the TSS value on fresh-cut mangoes fruit. The thicker the aloe vera gel, the lower the TSS value. This is because the high gel dilution ratio makes the fresh-cut condition of the manggoes fruit too impermeable, resulting in anaerobic fermentation and the mangoes begin to rot. According to [19] when the fruit is decomposed and damaged, the sugar content in it will be degraded, so that the TSS value will decrease.

Table 5

TSS ( ${ }^{\circ}$ Brix) Fresh-cut Mangoes Day 5 and 10

\begin{tabular}{cccc}
\hline Treatment & \multicolumn{3}{c}{ Mangoes (day) } \\
\cline { 2 - 4 } & 0 & 5 & 10 \\
\hline 1. & $22.80 \mathrm{a}$ & $23.00 \mathrm{~d}$ & $20.60 \mathrm{~b}$ \\
2. & $22.80 \mathrm{a}$ & $21.90 \mathrm{f}$ & $21.30 \mathrm{a}$ \\
3. & $22.80 \mathrm{a}$ & $22.00 \mathrm{ef}$ & $21.00 \mathrm{ab}$ \\
4. & $22.80 \mathrm{a}$ & $23.40 \mathrm{c}$ & $20.70 \mathrm{~b}$ \\
5. & $22.80 \mathrm{a}$ & $23.80 \mathrm{~b}$ & $21.20 \mathrm{a}$ \\
6. & $22.80 \mathrm{a}$ & $24.60 \mathrm{a}$ & $20.10 \mathrm{~b}$ \\
7. & $22.80 \mathrm{a}$ & $22.21 \mathrm{e}$ & $22.21 \mathrm{a}$ \\
8. & $22.80 \mathrm{a}$ & $22.20 \mathrm{e}$ & $21.70 \mathrm{a}$ \\
9. & $22.80 \mathrm{a}$ & $21.80 \mathrm{f}$ & $22.20 \mathrm{a}$ \\
\hline
\end{tabular}


The average TSS value of fresh-cut mangoes on day 5 and day 10 ranged from $(20,10$ $24,60 \mathrm{oBrix})$. Aloe vera gel can maintain the fresh-cut TSS of mangoes. This is in line with [20] that the edible coating can inhibit the metabolic rate of polysaccharides so that the TSS content can be maintained. The fruit is ripening and there are oxidative changes of complex materials, such as carbohydrates, proteins, and fats to form simple sugars, namely glucose, fructose and sucrose.

\subsection{Water content}

The combination of a 1: 0 dilution ratio of aloe vera gel with 1 minute immersion time can maintain the stability of the moisture content in the fresh-cut mangoes fruit. However, in the combination of the dilution ratio with other immersion time, there was an increase in water content on the 5th day and a decrease on the 10th day. The increase in water content on the 5th day was caused by the ripening and respiration processes which break down the starch and produce glucose, water, and energy and the decrease in water content on the 10th day was due to the transpiration process which evaporates the water. This opinion is in line with [21] that the higher the level of fruit maturity, the respiration rate will increase, but after the fruit reaches optimum maturity, the respiration rate will decline again. The average value of fresh-cut manggoes fruit moisture on the 5th and 10th days ranged from (81.41-86\%). The highest water content value was obtained in the combination of aloe vera gel dilution ratio of 1: 0 with immersion time of 3 minutes and the lowest was in the combination of dilution ratio of aloe vera gel 1: 2 with immersion time of 3 minutes. This shows that the aloe vera gel can maintain the stability of the moisture content in the fresh-cut mangoes. This opinion is in line with [22], that coating with aloe vera gel can close the stomata on fresh-cut mangoes so that the water evaporation process is reduced.

Table 6

Water Content (\%) Fresh-cut Mangoes Day 5 and 10

\begin{tabular}{cccc}
\hline Treatment & \multicolumn{3}{c}{ Mangoes (day) } \\
\cline { 2 - 4 } & 0 & 5 & 10 \\
\hline 1. & $80.91 \mathrm{a}$ & $82.66 \mathrm{bc}$ & $82.88 \mathrm{ab}$ \\
2. & $80.91 \mathrm{a}$ & $82.75 \mathrm{bc}$ & $81.48 \mathrm{c}$ \\
3. & $80.91 \mathrm{a}$ & $86.00 \mathrm{a}$ & $81.93 \mathrm{bc}$ \\
4. & $80.91 \mathrm{a}$ & $82.70 \mathrm{bc}$ & $82.95 \mathrm{a}$ \\
5. & $80.91 \mathrm{a}$ & $85.36 \mathrm{ab}$ & $81.89 \mathrm{bc}$ \\
6. & $80.91 \mathrm{a}$ & $83.51 \mathrm{abc}$ & $83.28 \mathrm{a}$ \\
7. & $80.91 \mathrm{a}$ & $84.15 \mathrm{abc}$ & $81.43 \mathrm{c}$ \\
8. & $80.91 \mathrm{a}$ & $82.01 \mathrm{c}$ & $82.61 \mathrm{ab}$ \\
9. & $80.91 \mathrm{a}$ & $83.74 \mathrm{abc}$ & $81.41 \mathrm{c}$ \\
\hline
\end{tabular}

\subsection{Vitamin C}

Based on the observations, it shows that the combination of 1: 2 dilution ratio of aloe vera gel with 2 minutes of immersion time can maintain the vitamin $\mathrm{C}$ content on the 5 th and 10th days. A very significant decrease in vitamin $C$ levels from day 0 to day 5 could be caused by the ripening process of fresh-cut mangoes, wherein the ripening process there was a decrease in organic acids. This reduction in organic acids is thought to be used in the process of respiration or conversion to sugar [11]. This is in line with the opinion of [1] that the decrease in vitamin $\mathrm{C}$ content is due to evaporation or water diffusion. The decrease in vitamin $\mathrm{C}$ is due to the nature of vitamin $\mathrm{C}$ which is easy to dissolve in water and is easily oxidized. The average value of fresh-cut mangoes vitamin $\mathrm{C}$ ranged from $(23.63-35.60 \mathrm{mg} / 100 \mathrm{~g})$. The highest and lowest values of vitamin $\mathrm{C}$ were obtained in the treatment of aloe vera gel dilution ratio of 1: 1 with an immersion time of 3 minutes. This shows that the edible coating treatment can form a layer that is good enough to inhibit the process of 
respiration and transpiration so that the decrease in vitamin $\mathrm{C}$ content in fresh-cut mangoes can be inhibited. This opinion is also in line with [4], the basic material of edible coating which is hydrophilic has good barrier properties against oxygen, carbon dioxide, and lipids. The presence of an edible coating can inhibit the entry of oxygen into the fruit which destroys vitamin $C$ through an oxidation reaction.

Table 7

Vitamin C (mg / 100g) Fresh-cut Mangoes Day 5 and 10

\begin{tabular}{cccc}
\hline Treatment & \multicolumn{3}{c}{ Mangoes (day) } \\
\cline { 2 - 4 } & 0 & 5 & 10 \\
\hline 1. & $73.19 \mathrm{a}$ & $30.39 \mathrm{a}$ & $27.64 \mathrm{a}$ \\
2. & $73.19 \mathrm{a}$ & $28.08 \mathrm{a}$ & $27.41 \mathrm{a}$ \\
3. & $73.19 \mathrm{a}$ & $30.57 \mathrm{a}$ & $23.86 \mathrm{a}$ \\
4. & $73.19 \mathrm{a}$ & $30.80 \mathrm{a}$ & $26.10 \mathrm{a}$ \\
5. & $73.19 \mathrm{a}$ & $28.53 \mathrm{a}$ & $28.99 \mathrm{a}$ \\
6. & $73.19 \mathrm{a}$ & $35.60 \mathrm{a}$ & $23.63 \mathrm{~b}$ \\
7. & $73.19 \mathrm{a}$ & $26.11 \mathrm{a}$ & $23.72 \mathrm{~b}$ \\
8. & $73.19 \mathrm{a}$ & $28.33 \mathrm{a}$ & $28.30 \mathrm{a}$ \\
9. & $73.19 \mathrm{a}$ & $23.74 \mathrm{a}$ & $23.74 \mathrm{~b}$ \\
\hline
\end{tabular}

\section{Conclusion}

The best treatment combination is obtained from the treatment ratio of aloe vera gel dilution with distilled water 1: 1 with immersion time of 3 minutes with a weight loss value of $1.40 \%$, color $63.12 \Delta \mathrm{E}$, texture $6.82 \mathrm{~N}, \mathrm{pH} 4.65$, TSS $24.60^{\circ}$ Brix, $83.51 \%$ and vitamin $\mathrm{C}$ content of $35.60 \mathrm{mg} /$ $100 \mathrm{~g}$. The combination of the dilution ratio of aloe vera gel with distilled water and immersion time can affect delaying physicochemical change of fresh-cut mangoes at cold storage $(7 \pm 1)^{\circ} \mathrm{C}$. There was a decrease in weight loss, color, texture, $\mathrm{pH}$, moisture content, and vitamin $\mathrm{C}$.

\section{Acknowledgments}

The authors are grateful to the Ministry of Research, Technology and Education Republic of Indonesia and the Rector of Warmadewa University for funding and supporting this research. The authors are also grateful to all colleagues for their assistance.

\section{References}

[1] Alikhani, M. 2014. Enhancing Safety and Shelf Life of Fresh-cut Mango by Application of Edible Coatings and Microencapsulation Technique. Food Science \& Nutrition. 2(3): 210-217. doi: $10.1002 / \mathrm{fsn} 3.98$

[2] Suriati, L., Utama, I M.S., Harsojuwono, B. A., and Gunam, I B. W. 2020a. Stability of Aloe Vera Gel as Edible Coating. IOP Conf. Series: Earth and Environmental Science, 411 (2020) 012053.DOI: 10.1088 / 1755-1315 / 411/1/012053

[3] Siddiqui W., Chakraborty I., Ayala-Zavala J.F., Dhua R.S. 2011. Advances in Minimal Processing of Fruit and Vegetables: A Review. Journal Scientific \& Industrial Research. 70: 823-834

[4] Suriati, L., Utama, I M.S., Harsojuwono, B. A., and Gunam, I B. W. 2020b. Physicochemical Characteristics of Fresh-cut Tropical Fruit During Storage. International Journal of Advanced Science and Engineering Information Technology, 10 (4): 1731-1736.

[5] Suriati1, L., and Utama, I M.S. 2019. Characteristic Fillet of Aloe Vera Gel as Edible Coating. J. Phys.: Conf. Ser, 1402 066021.DOI: 10.1088 / 1742-6596 / 1402/6/066021

[6] Winarti, C., 2011. Application of Edible Coating Based on Sago Starch with Addition of Vitamin C to Paprika: Consumer Preferences and Microbiological Quality.

[7] Suriati, L., Utama, I M.S., Harsojuwono, B. A., and Gunam, I B. W. 2020c. Incorporating Additives for Stability of Aloe Gel Potentially as an Edible Coating. AIMS Agriculture and Food, 5 (3): 327-336. 
[8] Dhall, R. K., 2013. Advances in Edible Coatings for Fresh Fruits and Vegetables: a Review. Journal: Critical Review Food Science Nutrition. 53(5): 435-450. doi:10.1080/ 10408398.2010.541568

[9] Alsuhendra, Ridawati, and Agus, I.S. 2011. Effect of Edible Coating Use on Weight Loss, pH and Organoleptic Characteristics of Cut Fruits in Dessert Serving. Jur. IKK Faculty. Engineering Jakarta State University (UNJ).

[10] Suriati, L., Utama, I M.S., Harsojuwono, B. A., and Gunam, I B. W. 2020d. Ecogel Incorporated with Nano-additives to Increase Shelf-life of Fresh-cut Mango. Journal of Applied Horticulture, 22 (3): 189195

[11] Galgano, F., N. Condelli, F. Favati, V. Di_Bianco, G. Perretti and M.C. Caruso, 2015. Biodegradeable packaging and edible coating for fresh-cut fruits and vegetables. Ital. J. Food Sci., 27.

[12] Ayranci, E., and Tunc, S. 2004. The Effect of Edible Coatings on Water and Vitamin C Loss of Apricots (Armeniaca vulgaris Lam.) and Green Peppers (Capsicum annuum, L.). Food Chem., 87:339-342.

[13] James, J.B., Ngarmsak, T. 2010. Processing of fresh-cut tropical fruits and vegetables: A Technical Guide. Food and Agriculture Organization of the United Nations Regional Office for Asia and the Pacific Bangkok

[14] Ergun, M., Satici, E. F. 2012. Use of Aloe vera Gel as Biopreservative for 'Granny Smith' And 'Red Chief' Apples M., J. Anim.Plant Sci. 22(2): 363.

[15] Marpudi, S. L., Abirami, L.S.S., Puskhala, R., Shrividya, N. 2011. Enhancement of Storage Life and Quality Maintenance of Papaya Fruits Using Aloe vera Based Antimicrobial Coating. Indian Journal of Biotechnology. 10(1): 83-89. http://hdl.handle.net/123456789/ 10956

[16] Widaningrum, Miskiyah and Winarti, C. 2015. The edible coating based on sago starch with antimicrobe addition of lemongrass oil on red bell pepper. Agritech 35 (1): 53-60.

[17] Tafzi, F. (2010) Study on the use of an edible coating to extend the shelf life of minimally processed pineapples. Splash 108: 11-15.

[18] Falguera, V., Quintero, J. P., Jimenez, A., Munoz, J. A. and Ibarz, A. (2011). Edible coating and films: Structures, active function, and trends in their use. Trends in Food Science and Technology 22: 292-303

[19] Galgano, F., Condelli, N., Favati, F., Di_Bianco, V., Perretti, G., Caruso, M. C. 2015. Biodegradeable Packaging and Edible Coating for Fresh-cut Fruits and Vegetables. Ital. J. Food Sci., vol. 27. https://doi.org/10.14674/1120-1770/ijfs.v70

[20] Saberi, B., Chockchaisawasdee, S., Golding, J.B., Scarlett, C.J.\&Stathopoulos, C.E. (2017). Physical and mechanical properties of a new edible film made of pea starch and guar gum an affected by glycols, sugars, and polyols. Int. J. Biol. Macromol 104, 345-359

[21] Hewet, E.W. 2013. Postharvest Innovation: Current Trends and Future Challenges in The Global Market. Institute Institute of Food, Nutrition and Human Health, Massey University, Auckland New Zealand

[22] Mikkonen, K. S., Tenkanen, M. 2012. Sustainable Food-packaging Materials Based on Future Biorefinery Products: Xylans and Mannans. The trend in Food Science Technology 28(2):90-102. https://doi.org/10.1016/j.tifs.2012.06.012Rex (1984). 